\title{
Chapter 6 \\ Epistemological Issues in Qualitative Migration Research: Self-Reflexivity, Objectivity and Subjectivity
}

\author{
Theodoros Iosifides
}

\subsection{Introduction}

This chapter concerns some crucial epistemological issues related to qualitative research methods in general and qualitative findings in particular, with special emphasis on migration processes. First, I discuss some central epistemological matters of qualitative social research in general, related to the complex and, sometimes, challenging or problematic relations between ontology, epistemology and methodology. Then, I proceed to the more specialized discussion of issues of interest within the context of this chapter such as:

- Self-reflectivity: the power differentials between participants and researchers during and after the research process and thus the need for constant reflexivity of the researcher. Moreover, the need to place self-reflexive elaborations and subsequent modifications at the centre of the research process and as powerful means for the evaluation and interpretation of qualitative data and findings

- Subjectivity and objectivity in qualitative migration research: here, I offer a critique to the traditional hostility of qualitative methods to the notion of objectivity - which is always equated to the positivist conceptualization of it - and I propose different and alternative notions of objectivity and truth which hopefully contribute to the dismantling of the dichotomies of objectivity/subjectivity in social research in general and qualitative migration research in particular.

Finally, the chapter concludes by stressing the need for qualitative migration research to become more relevant in contemporary social relations, which are characterized by extreme injustice and inequality. Those, in my view, can be reached by

T. Iosifides $(\triangle)$

University of the Aegean, Mytilene, Greece

e-mail: iwsifidis@ aegean.gr 
reconciliating notions of self-reflexivity, subjectivity, objectivity, interpretation and causality in qualitative methods.

\subsection{Some Ontological and Epistemological Issues in Qualitative Migration Research}

In this part of the paper, I discuss some crucial issues of ontology and epistemology in social sciences in general, and in qualitative research in particular, and how ontological and epistemological commitments are implicitly or explicitly linked with methodological choices and practices. I give special emphasis in critiquing some of the most widespread ontological and epistemological accounts in contemporary qualitative research, those of interpretivism and social constructionism, and offer critical realist meta-theoretical assumptions as a viable alternative (Iosifides 2011a, 2012). Consequently, I proceed with examining qualitative research practice on migratory processes which is simultaneously interpretive and explanatory, and avoids both the shortcomings of positivism and the traps of relativism of any persuasion (see Hammersley 2008, 2009).

It is more than common in contemporary qualitative inquiry in its broadest sense, to be conceptualised as inherently linked with certain meta-theoretical and epistemological approaches, notably those of interpretivism and various versions of social constructionism and post-structuralism. Thus, Tsiolis (2014, p. 29), for example, directly connects qualitative methods with the interpretivist approach, adopting the extremely widespread position that the entirety of social reality is a symbolic construction. Conceptualizations of qualitative methods such as this, inherently connect qualitative and quantitative methods with certain meta-theoretical and epistemological theses and, explicitly or implicitly, reproduce the unfruitful dichotomy between qualitative and quantitative research (Lim and Wieling 2004; Iosifides 2011b). I think that although it is beyond dispute that positivism and neo-positivism opt for quantitative methods while interpretivism and social constructionism for qualitative ones, the opposite is not the case and has not to be the case. There are no separate qualitative and quantitative paradigms and epistemologies, that is, there are no inherent and necessary connections and linkages of different methods to certain epistemological principles. Different methodological strategies and approaches are appropriate for the investigation of different aspects and dimensions of social reality, phenomena and processes. The latter are characterised by aspects and dimensions of more qualitative or quantitative character and can be approached by the respective methods or by their combination under any meta-theoretical scheme. The real question is how ontological, epistemological and methodological choices, either explicit or implicit, may enhance explanatory power and produce meaningful answers to research questions.

For example, the phenomenon of deportations and the socio-political processes which are associated with it, are characterized by various aspects, some of which 
are more qualitative and some more quantitative in character. Thus, a quantitative researcher might be more interested in the number of deportations states are engaged with every year and to the quantification of state categorizations of wanted and unwanted migrants. A qualitative researcher might be more interested in the investigation of how social relations produce racist and discriminatory practices such as deportations, subjectification processes of deportees, the role of securitization discourses and associated material practices to migrant selectivity and so on (see, for example, de Genova 2002; Skleparis 2016a, b). Thus, I advocate a kind of qualitative methodological approach which treats qualitative data as evidence for describing, analyzing and explaining broader social realities, phenomena and processes. This kind of qualitative research practice is re-oriented from its strong linkages with certain versions of interpretivism and social constructionism avoiding their weaknesses and pitfalls (see Iosifides 2011b, 2012).

Interpretivism, or to be more precise, certain versions of it, reduce social reality to interpretations, beliefs and conceptualizations of it, denying any notion of independence of various aspects of reality from individual and collective interpretations. In this way, this kind of interpretivism adopts a "narrow" ontological position reality is confined to agential action governed by subjective and inter-subjective interpretations and meanings. This approach derives from the epistemological thesis according to which our knowledge of reality cannot move beyond individual and collective meanings and interpretations (see Hartwig 2007). Moreover, this kind of interpretivism is totally hostile to any notion of causality in the social world and causal explanation of social phenomena and processes replacing these notions with verstehen, that is, understanding of meaning and meaningful actions of social agents. This is because those versions of interpretive thinking equate causality and causal explanation with the positivist conceptualization of it and implicitly adopt its positivist definition. They cannot move beyond the positivist notion of causality - a successionist, independent and distinct cause and effect view of it - and cannot imagine any alternatives to it. Thus, the rightful rejection of positivist causality leads to the abandonment of any notion of causality and causal explanation in the social world.

The above characteristics of this version of interpretivism, which is the most widespread in contemporary qualitative research, notably the exhaustion of reality to interpretations and meanings, the abandonment of causal thinking of any manner and the almost total prioritization of agential subjectivity and action are simultaneously its greater weaknesses (see Wengraf 2001; Willis 2007) First, they do not allow for adjudicating between more and less valid meanings, beliefs and interpretations, and they do not acknowledge misunderstandings and false (not just different) interpretations (Iosifides 2011a). Second, they dissociate understandings of the point of view of social actors from explaining them as well, that is from making an effort to explore the causal conditions which allowed certain beliefs, meanings and interpretations to arise and not others. And finally, they reduce social reality to subjective agential action, ignoring and neglecting a series of other factors and causal powers such as materiality, structural conditioning, social power asymmetries or cultural dynamics (see Elder-Vass 2010, 2012). 
Now, it is extremely difficult to imagine the congruent functioning of those features of this version of interpretivism in practice, both in ordinary everyday life and in qualitative research practice. As Potter and López (2001, p. 9) point out:

\begin{abstract}
We can (and do!) rationally judge between competing theories on the basis of their intrinsic merits as explanations of reality. We do so both scientifically and in everyday life. If we could not we would not be very frequently successful in even our most mundane activities. Science, in one sense at least, is merely a refinement and extension of what we do in the practical functioning of everyday life. However, it is a refinement!
\end{abstract}

The necessity of adjudicating between different meanings and interpretations, of acknowledging the complexity and ontological depth of reality and of locating agential meaning making and action within the broader interplay of different and distinct causal powers becomes clearer if we think about some examples from migration research. For instance, conducting qualitative biographical research about immigrant lived experiences, subjectivities and interpretations within certain versions of interpretive thinking - for example, phenomenological or symbolic interactionist approaches - is associated with the explicit or implicit premise according to which interpretations and meanings of immigrants refer to and are the products of the research interactional context and not to any reality or realities "out there" (see Iosifides and Sporton 2009). Thus, it is very common that within such ontological and epistemological frameworks:

\begin{abstract}
...biographical narratives are the mere product of the communicative interaction between the researcher and the research participant in the present (that is at the time of interaction), and cannot be used in order to highlight the impacts and role of any 'real' processes (see Tsiolis 2006). Thus, a narrative of an immigrant about her trajectory of spatial and social mobility in the host country, about passing different stages and phases resulted in modified social situation and relations, have value only as 'accounts' that is as interpretations or discourses. (Iosifides and Sporton 2009, p. 105)
\end{abstract}

Of course, the consequences of such thinking are more than important. For example, they are related to the inability to account for how exactly immigrant subjectivities and meanings are formed and how they are shaped and influenced by unacknowledged and uncontrolled by individual immigrant factors such as the mostly structural process of categorizing some geographical mobile people as migrants. They are also related to the abandoning of efforts to formulate criteria for separating valid from invalid beliefs and interpretations. This is, of course, understandable when reality and interpretations of reality are epistemologically taken to be the same thing, but this kind of thinking leads inevitably to the position that all interpretations have equal validity and the inability to account for false interpretations, beliefs and meanings (see Sayer 2000; Manicas 2009). Thus, racist and xenophobic interpretations and categorizations of migrants are false interpretations in the sense that they are not related to any real features of the categorized groups which, of course, exist outside of the interactional context that such interpretations are formed (see Carter 2000). At the same time, those beliefs have real causal impacts on social processes as they lead to social and material de-valuation of certain social groups and categories. 
Now, let me briefly discuss social constructionism and, more specifically, the version of the so called "strong", "strict" or radical social constructionism (ElderVass 2012), which influences contemporary qualitative research in general and qualitative migration research in particular. This kind of social constructionism differs from interpretivism in adopting a macro perspective and in reducing human agency, subjectivity and agential action to discourse and discursive practice (see Sayer 2000; Carter 2000). This kind of social constructionism views “....reality, including social reality, as inseparable from socially constructed knowledge and its understandings" (Iosifides 2011b, p. 110). Thus, social phenomena, processes and realities are constructed by language and discourse and, epistemologically, we only have access to different discursive constructions of the social world and never to processes, social conditions and causal mechanisms, which exist and exert their influence independently of how they are thought of, conceptualized and linguistically described. Of course, it is impossible to proceed here with an adequate analysis of the whole spectrum of constructionist thinking due to space constraints and because such a task exceeds the purposes of the present chapter. Nevertheless, I can briefly discuss some serious limitations and flaws of such kind of thinking associated with an example from migration studies indicating its negative effects on qualitative research practice.

First, this kind of social constructionism views linguistic forms, discourses and discursive practices as all pervasive and as constitutive of social relations, practices and processes. Constructionists of this kind fail to acknowledge, or explicitly declare, that there cannot be any separation between discursive and non- or extra discursive dimensions of social reality (see Laclau and Mouffe 1985). To be more precise, they fail to acknowledge that in many cases discourse can have access to realities beyond it. Moreover, they cannot imagine or account for that discourses may be simultaneously constitutive of social phenomena and constituted by realities ontologically existent separately from them. Thus, this version of social constructionism is a kind of discursive reductionism, which do not allow for the account and researching of the whole range of social complexity and ontological depth of social reality. Second, radical social constructionism is based on a view of a much contested and critiqued view of language as a closed, self-referential system of signs (see Archer 2000; Potter 2001), ignoring the referential potentialities of language and discourse and the role of practice in social life, which always exceeds and goes beyond linguistic forms and constructions (Sayer 2000; Nellhaus 2001; Fairclough et al. 2004). Finally, radical social constructionism cannot avoid internal inconsistencies and contradictions and, especially, relativism, which undermines critical and emancipatory social research. This is because relativist thinking connects any assertion about social reality with a certain conceptual scheme, which is rendered equally arbitrary and conventional with all others and thus does not allow for any kind of access to mind-independent realities (see Hammersley 2008). But as Hammersley (2009, p. 12) rightly points out:

To propose that there are no phenomena existing independently of our accounts of them is to put forward a knowledge claim. Yet if the validity of all knowledge claims is relative to 
some socio-cultural framework or context, then this is true of this claim as well. And this means that in terms of some other frameworks or contexts it will be false.

Moreover, the inability to adjudicate between different discourses through relating them to extra-discursive realities is not resolved and continues to be a major problem even when the criteria of judging between different situations and conditions are ethical and moral. This is because relativist and discourse-reductionist thinking is all embracing and is not possible to limit it to the cognitive-epistemic realm. Thus, Hammersley (2009, p. 21) again stresses that:

From a relativist point of view, what is morally acceptable is so only in the context of a particular cultural framework, and could well be unacceptable from other perspectives. In these terms, the implications of relativism are the same as regards both epistemic and moral standards; so why abandon the former while retaining the latter?

Now, the limitations and fallacies of this kind of thinking and its disadvantages as regards social-scientific, critical, emancipatory qualitative research practice on migration can be indicated through the example of securitization research. Securitization means the conceptualisation and treatment of immigrants as a threat and problem, and is connected with illegalization and criminalization of migration and the whole range of associated actions and policies against cross-border mobility by certain categories of people (see Karyotis and Skleparis 2014). Methodologically, qualitative research on the field is based on the analysis of discursive practices of various social/institutional actors and, epistemologically, it has been influenced by various schools of thought, notably the constructionist Copenhagen School speech act securitization theory (see Squire 2009). Squire (2009), following partially this line of thinking and adopting the discourse theory of Laclau and Mouffe (1985) declares that:

...there exists a world and objects that are independent of discourse, but that these are only accessible through a discursive frame. When it comes to the process of analysis, such an approach is thus decidedly anti-objectivist, because it is based on the assumption that 'natural facts are also discursive facts ... (Squire 2009, p. 31)

\section{And elsewhere:}

There are thus two ontological assumptions on which an anti-objectivist theory of securitization is based. First, it rests on the assumption that any purely objective meaning or identity is impossible. Rather, it examines the relational processes that are inherent both to the construction of meaning and to the construction of identity. Second, it rests on the assumption that a discursive order can never be complete, or that it can never reach the point of absolute closure. (Squire 2009, p. 31)

While I agree with most of the above remarks, I think that this line of thinking is characterized by all problems of radical constructionist approach and, eventually, limits critical and emancipatory potentialities and this, of course, irrespective of the political and theoretical theses of scholars who follow it. First, it equates the positivist notion of objectivity with objectivity in general. It cannot imagine that there may be certain inter-subjective discourses and certain conceptual schemes and frameworks that grasp extra-discursive realities quite accurately. Actually, in many instances, the points of view of the dominated and exploited, such as those of 
contemporary criminalized or illegalized migrants and the theoretical elaborations based on them, can grasp broader realities of capitalist relations across different geographical scales extremely accurately, because they derive from specific positions in social hierarchies (see Danermark et al. 2002). Second, it leans towards epistemic and inevitably moral relativism. For if discourses construct reality and we have access only to them and not to the extra-discursive realm, then what are exactly the criteria of choosing among securitizing and non-securitizing discourses? As we indicated above, within relativist frameworks of thinking, there are not epistemic, cognitive or moral criteria to do so. Moreover, the assertion that we resist - theoretically and, some of us, in practice as well - securitizing discourses because they result in deeper exploitation and social injustice will not do either. For, given the relativist, radical constructionist reasoning, the realities of "exploitation" and "social injustice" are also discursive constructions and are connected to certain conceptual schemes and, thus, we cannot assert that they exist outside those specific discourses and conceptual schemes.

Now, I propose a way of overcoming the limitations of both interpretivist and radical constructionist thinking in qualitative research in general and qualitative migration research in particular, without stepping back to positivism and neopositivism and without losing the invaluable qualities of interpretive and constructionist approaches. This way is to pay attention to the ontological, epistemological and methodological theses of critical realism, which integrates interpretive and causal reasoning, the notion of a mind-independent reality with moderate constructionism (Elder-Vass 2010), subjectivity with a different notion of objectivity and qualitative with quantitative methodological approaches (Danermark et al. 2002; Iosifides 2011a). Understandably, I cannot elaborate on the whole richness and complexity of the critical realist approach, but I can refer to some of its most basic premises and more importantly to the ways that critical realist meta-theory modifies qualitative research practice.

Critical realism asserts that some social entities, processes and mechanisms exist independently from their interpretations and conceptualizations or from their identification as such (see Bhaskar 1993, 1998; Fleetwood 2005). This thesis indicates the importance and emphasis that realism gives on ontology. In other words, what exists in reality beyond interpretations and discursive formations. For realists then, the social world is characterized by ontological depth that is, by a complex spectrum of phenomena, processes, mechanisms and causal powers, which may be unobservable or non-acknowledgeable but real, in the sense that they exert influences and contribute causally to the production of certain social outcomes (Cruickshank 2003). Although our access to the social world and its phenomena and processes is possible only through our conceptual schemes, interpretative repertoires, theoretical schemes and discursive formations, in many instances, some of them refer to features which are part of the ontology of the social. This is because for realists, language has, among others, referential potentialities as well and it is not conceptualized as a closed, self-referential system, but as an open one and in constant interaction with practice and the world outside it (see Archer 2000). Moreover, critical realism places causality at the center of social scientific inquiry and research of any kind, 
but it proposes a far more different and elaborate notion of causality from that of positivism. It is a notion of causality as generative and of causal powers as emergent from the relational makeup of social entities (Sayer 1992; Outhwaite 1998; ElderVass 2010, 2012). Thus, for critical realism, the social world is viewed as stratified and emergent, and phenomena and social processes are produced through the constant interaction between human, individual and collective agency and action, social material structures and ideational discursive formations. Within this framework, agential interpretations and reasons are causes of social action and discourses are emergent from social interaction and exert causal influences. So, critical realists deeply appreciate the role of individual/collective interpretative action and engage with discursive research and analysis (see Fairclough 2003, 2005), but they avoid agential or discursive reductionism and relativism by constantly relating them with social elements beyond them and investigating the ways in which they interact with one another.

Within the above framework, qualitative research disassociates itself from the epistemological premises of some unproductive versions of interpretivism and social constructionism and means:

The 'art' of connecting rather than conflating: individual meanings and perspectives with their referents and thus assessing their adequacy as well; discursive with non-discursive practices and social relations; perceptions about the character of social practices and courses of action with the real character of practices and courses of action; agential with structuralmaterial and cultural-ideational causal properties and powers. (Iosifides 2011b, p. 17)

It is a kind of qualitative research practice that places equal emphasis on meaningmaking and discursive practices and on the material and societal conditions which facilitate their formation, material and other interests, social relations of any kind, practices and doings of social actors. This kind of qualitative research has as its basic aim the in-depth investigation of different causal powers - agential, materialstructural and cultural-ideational -, how they interact with each other and how they produce certain outcomes.

Allow me now to return to securitization research. Under critical realist premises, qualitative research on securitization, criminalization and illegalization of migration investigates securitizing discourses and associated actions within broader socio-economic and political contexts and developments and how those discourses constitute migration as a threat and danger and are simultaneously constituted by extra-discursive societal-material interests (see also King, Chap. 3 in the present Volume). It also investigates how securitizing discourses facilitate power-driven, unequal and unjust social relations in various spatial scales and how they are simultaneously facilitated by those relations. For example, the in-depth examination of how the capitalist crisis and the associated changes in the capitalist social and economic relations globally, especially after the 1990s, created the need for even cheaper, more precarious, more disciplined and without rights working force and, thus, to illegalization of migration, would be a necessary theoretical baggage in this kind of qualitative research practice (see Scripta 2013). Finally, this kind of qualitative research on securitization of migration seeks to causally explain it, to uncover 
the domineering and exploitative conditions which allow its rise and persistence, to indicate how things work in reality about the matter and to offer prospects for changing its background conditions and resisting it.

\subsection{False Dichotomies: Subjectivity, Objectivity and the Legacies of Positivism}

In this section, I offer some brief thoughts aiming to the dismantling of the dichotomy between objectivity and subjectivity in qualitative methods, using examples from migration research (Sayer 2000; Iosifides 2011b). I consider this dichotomy an unnecessary remaining of positivist thinking and offer a critical realist alternative of both subjectivity and objectivity, which can be combined together. For classical positivists, human subjectivity is excluded from the scientific endeavors of discovering absolute truths and achieving objectivity (see Leontidou 2005). Thus, the positivist notion of objective knowledge presupposes an "Archimedean position" or a "God's eyes view" of reality (Iosifides 2011a), which is an impossibility as all knowledge is always conceptually mediated. Moreover, objectivity and truth for positivists are equated with and restricted to transparent correspondence of thought to sense experiences and to the formulation of universal, ahistorical "laws" (see Andriakaina 2009). Interpretivists and social constructionists rightly reject these notions, but they usually adopt the position that objectivity in social scientific inquiry is impossible. In other words, they endorse the positivist definition of objectivity as the only available and possible, and then reject both this definition and objectivity in general. Thus, they restrict reality either to subjective and intersubjective meanings and interpretations or to discursive formations and practices, and thus adopt, either implicitly or explicitly, relativist and conventionalist ways of thinking (see Hibberd 2005).

Critical realism offers a radically different notion of objectivity and stresses that concept mediation of knowledge and reality does not preclude truth and objectivity. As Moya (2000, p. 12) asserts:

(1) all observation and knowledge are theory mediated and that (2) a theory-mediated objective knowledge is both possible and desirable. They replace a simple correspondence theory of truth with a more dialectical causal theory of reference in which linguistic structures both shape our perceptions and refer (in more or less partial and accurate ways) to causal features of the real world. And they endorse a conception of objectivity as an ideal of inquiry rather than as a condition of absolute and achieved certainty.

Now moving at the level of social actors and relations, critical realist ontological and epistemological approach views subjectivity and inter-subjectivity as integral parts of reality. So, subjectivity and inter-subjectivity can be approached in a way that valid and objective (although fallible) knowledge about them is possible. Moreover, subjective and inter-subjective beliefs, meanings and interpretations of reality and social experiences may vary in how they accurately describe realities 
beyond them. Qualitative research has an invaluable role and can contribute significantly to the assessment of accuracy of such meanings and interpretations as both more or less accurate interpretations play a vital role in social change (or stasis). For realist qualitative researchers then, subjective and inter-subjective meanings and interpretations along with perceptions connected to personal and social identity are treated as theories about reality, which can be assessed for their truthfulness and validity (Iosifides 2011a). Thus,

...there is a cognitive component to identity that allows for the possibility of error and of accuracy [emphasis added] in interpreting the things that happen to us. It is a feature of theoretically mediated experience that one person's understanding of the same situation may undergo revision over the course of time, thus rendering her subsequent interpretations of that situation more or less accurate. (Moya 2000, p. 83)

This is extremely crucial for researching migration processes and phenomena, as the role of certain interpretations and discourses in mystifying reality is vital. Some beliefs, subjective meanings and public discourses have to be necessarily and objectively false in order to contribute to the reproduction of objectively real and true conditions of domination and exploitation. For example, racism of any form and type and form, either every day, institutional, collective or political, is one such set of interpretations and discourses which tend to mystify reality and obscure real relations of domination and exploitation. Combined with the needs of capitalist accumulation in different spatial scales and with political efforts for popular mobilization through scapegoating and systematically devaluating certain categories of people, racist ideas, beliefs, interpretations and discourses are contributing significantly to the production and reproduction of power inequalities and injustice. As such, realist qualitative researchers pay acute attention to them and conceptualize them as utterly wrong and false and not as just different constructions of reality derived from selfreferent signification systems (see Carter 2000). Moreover, researchers of this kind take into serious account the complexity of subjectivity formation and re-formation in time and causally connect subjectivity, inter-subjectivity, experiences and social positions of social actors (see Moya 2011; Walby 2009). They also take immigrant subjectivities and subjectivities about immigrants very seriously, but ontologically/ epistemologically and methodologically they move beyond them and they do that by assessing their adequacy, by causally linking them to realities outside them and by thoroughly investigating their role in either resisting or reproducing complex, intersecting social inequalities of gender, ethnicity, socio-economic level, migration status and so on (see Walby 2007).

\subsection{Power and Reflexivity in Qualitative Migration Research: The Case of Methodological Nationalism}

In the next two sections, I proceed by discussing some more specialized and specific issues concerning qualitative migration research, placing them within the lens of critical realist meta-theory. In this one, I discuss issues of power differentials between researchers and research participants in qualitative migration research and 
I extend this beyond the "classic" preoccupation about relations between researchers and research participants in the field. I give special emphasis on the dominant way that social sciences treat this "special" kind of mobility called migration, and the repercussions of the colonization of social scientific conceptualizations of migration by state categories. In other words, I raise the issue of methodological nationalism that is equating "societies" with nation-states and viewing migratory movements as exceptional and abnormal (see Glick Schiller 2007). I also stress that methodological nationalism poses one of the greatest dangers in researching migration today, due to its un-reflexive and power-driven character (see also Barglowski, Chap. 9 in the present Volume).

In migration research, matters of relations between the researcher(s) and research participants, reflexivity and positionality are of great importance, as they are part of or influence significantly the theoretical and conceptual frameworks at hand, the ways that data are collected and produced and the approaches within which findings are interpreted and presented (see Denzin and Lincoln 1994; Iosifides 2008). Qualitative researchers who investigate migration are or have to be extremely sensitive about such issues, as they are usually more intensely involved with the lives of people who, in most cases, found themselves in more disadvantaged positions in social hierarchies. Thus, matters of power differences between researcher(s) and research participants and a constant preoccupation with the positionality of the researcher(s) (that is, with the role of points of view, conceptual frameworks and theoretical categories) have to be at the center of qualitative inquiry. As migration researchers, being reflexive about our own positions in social settings, our own thought categories, beliefs, emotions, points of view and conceptual schemes, has to be an explicit and vital part of our research endeavors. Nevertheless, reflexivity and positionality can be exercised within different ontological and epistemological frameworks and can lead to different outcomes. Within certain versions of interpretivist and constructionist thinking analyzed in the previous section, reflexivity and positionality lead to the adoption of the idea according to which it is impossible to move beyond the specificities of various positionalities and points of view in order to discover how things work in reality (see Sayer 2000). On the contrary, for the critical realist meta-theoretical approach, reflexivity and positionality are not in contradiction with the goal of discovering the workings of real causal powers, but a basic part of it. Critical realists stress that some positions and some conceptual frameworks are more privileged than others in guiding researchers to explain social phenomena and processes more adequately (see Danermark et al. 2002).

The relation between theories/theoretical concepts and the properties of objects the concepts are referring to is not unambiguous and simple; nor is it arbitrary. All theoretical descriptions of reality are fallible, but not equally fallible. Theories and theoretical concepts are developed in relation to the experiences we obtain when we use them to understand reality. (Danermark et al. 2002, pp. 116-117)

In this point, critical realism shares notions of objectivity with other approaches, notably this of standpoint epistemologies and "strong objectivity" (see Harding 1993). 
Thus, the task of qualitative researchers influenced by critical realism is, through intense reflexive work, to find and adopt the adequate position and conceptual framework in order to explain phenomena and processes. I think that in the case of migration studies, this reflexivity work has to be done for the research field as a whole. I mean that, as qualitative migration researchers, we have to be reflexive about the conceptual and theoretical categories we use in order to study migratory phenomena, with the goal to adopt those frameworks which illuminate migration realities more truthfully and adequately. This presupposes abandoning the so called methodological nationalist way of thinking about and theorizing migration and avoiding thinking and theorizing cross-border mobility through the lens of state and other dominant categories, discourses and interpretations (Amelina et al. 2012). It also presupposes the adoption of the perspective of the subaltern, the dominated and the exploited and its refinement to theoretical schemes, which can explain contemporary migratory phenomena and simultaneously critique underlying real mechanisms of exploitation, domination, exclusion and injustice. In other words, it presupposed the engagement with what critical realists call "explanatory critiques":

Explanatory critiques entail proving certain ideas or beliefs to be false - that is, to be antithetical to the interests of their holders -, certain social relations to be exploitative and asymmetric and, in many instances, proving the necessity of holding false ideas for the reproduction of exploitative or oppressive social relations (Sayer 2000). (Iosifides 2011a, p. 46)

One such false idea, which is highly influential in contemporary migration studies, is methodological nationalism. Methodological nationalism “...is an ideological orientation that approaches the study of social and historical processes as if they were contained within the borders of individual nation-states. Nation-states are conflated with societies and the members of those states are assumed to share a common history and set of values, norms, social customs, and institutions" (Glick Schiller 2007, p. 43). Moreover, methodological nationalism entails the naturalization of notions of "nationhood", "national belonging", "cultural, national and ethnic identities" and contributes to nationalizing and ethicizing social relations masking power and class relations and antagonisms, as well as obscuring their nature under global capitalism. Methodological nationalism guides research practice, either quantitative or qualitative, which takes dominant categories and conceptualizations as given and natural and researchers influenced by it investigate social reality, including migratory phenomena and processes, as if state and national conceptualizations were true.

In migration related research, methodological nationalism leads or enhances

(1) the homogenization of national culture (2) the homogenization of migrants into ethnic groups - seen as bearers of discrete cultures - who arrive bearing cultural, class, and religious differences, and (3) the use of national statistics organized so that ethnic difference 
appears as an independent variable in the reporting of levels of education, health status, degrees of employment, and level of poverty. In other words, as they are currently constituted, migration studies and their ethnic studies counterparts contribute to the reinvigoration of contemporary nation-state building projects... (Glick Schiller 2007, pp. 43-44)

Although it is impossible here to review the extended literature on the matter, it has to be noted that, for critical realism, methodological nationalism is the false perspective to view and research migration and related phenomena and processes. Its falsity lies in the fact that it obscures the workings of real causal powers whose interaction produce certain categories of people who are described, labeled and treated as migrants.

Qualitative research can significantly contribute towards overcoming methodological nationalism due to its inherent characteristics, which are related to its intensive engagement with the lives of real people, real social relations and their interactional structural and cultural outcomes (Iosifides 2011b). First, the very term "migration" has to be used, discussed and analyzed with caution. Having in mind that no term is neutral, it has to be noted that "migration" is usually used to describe and give special meaning to spatial mobilities of certain poorer categories of people. Thus, "migration", through its whole baggage of conceptualizations about management, containment, discipline and control (Geiger and Pécoud 2012; Georgi and Schatral 2012), tends to obscure unequal and power-driven social relations and to naturalize the fact that, for some people, freedom of movement is demonized and, for others, is celebrated and encouraged. Second, qualitative migration research is valuable in the depth investigation of how boundaries between people are constructed and become effective and how unequal power relations are enhanced and reproduced through them (see Wimmer 2008). Qualitative migration research inspired by critical realism integrates the study of agential interpretations of any kind, of discursive formations, and of social practices and social relations with the aim to discover real generative mechanisms which produce contemporary migratory processes. The avoidance of methodological nationalism entails the focusing on the real character of social relations that exist independently of their interpretations and discursive descriptions and can be grasped under the adequate interpretations and discursive formations and, especially, those that are characterized by asymmetry and inequality. As Glick Schiller (2007, p. 62) asserts: “...migration studies with its rooting in the concerns of nation-state building projects have not only failed to address global political economy but also have not examined its relationship to several kinds of power including that which racializes and subordinates regions, populations, and localities". Finally, there is a necessity of the modification of the usual units of analysis in migration studies, such as naturalized ethnic or national groups towards the positioning of people in various structural, class and other power hierarchies (see Wimmer 2007; Weiss and Nohl 2012). 


\subsection{Concluding Remarks: Towards a More Relevant and Empowering Qualitative Migration Research Practice}

Finally, the concluding part of the chapter concerns some very brief thoughts regarding a kind of qualitative migration research which focuses on real causal processes of domination and exploitation across different spatial scales, does not become an integral part of state or other "migration management" policies and empowers both migrants and non-migrants social action towards social justice. In my view, this kind of qualitative migration research practice is better achieved under the critical realist meta-theoretical premises, because it integrates several crucial strengths and advantages, notably a critical stance, avoidance of relativism of any kind, relevance and explanatory potential.

First, adopting a critical stance of social relations of power inequality, exploitation and domination is extremely important for contemporary migration researchers who reject methodological nationalism and state-centered lens of viewing the social world. Employing qualitative methods which are inherently connected with getting closer to reality (see Wengraf 2001) contribute significantly to the enhancement of this stance.

Second, avoiding relativizing real relations of inequality, exploitation and domination along with the real causal powers which produce and reproduce them reinforce critical views and ideas and helps migration qualitative research to be relevant and make its points. This time, its relevance and utility does not concern states, administrative agencies or intergovernmental organizations, but movements and collectivities aiming to resist power asymmetries, fight anti-immigrantism (Doty 2003) and achieve freedom of movement for all people (Hayter 2004). Finally, this kind of qualitative migration research practice is explanatory as well. Apart from collecting and producing material on immigrant experiences, interpretations and actions, it seeks to explain migratory-related processes by accounting for certain causal generative mechanisms which lead to certain outcomes (Iosifides 2011a).

\section{References}

Amelina, A., Nergiz, D. D., Faist, T., \& Glick, S. N. (Eds.). (2012). Beyond methodological nationalism. Research methodologies for cross-border studies. New York: Routledge.

Andriakaina, E. (2009). Beyond positivism and postmodernism. Essays in historical sociology. Patras: Opportuna (in Greek).

Archer, M. S. (2000). Being human. The problem of agency. Cambridge: Cambridge University Press.

Bhaskar, R. (1993). Dialectic: The pulse of freedom. London: Verso.

Bhaskar, R. (1998). Philosophy and scientific realism. In M. Archer, R. Bhaskar, A. Collier, T. Lawson, \& A. Norrie (Eds.), Critical realism, Essential readings (pp. 16-47). London: Routledge. 
Carter, B. (2000). Realism and racism. Concepts of race in sociological research. London/New York: Routledge.

Cruickshank, J. (2003). Realism and sociology. Anti-foundationalism, ontology and social research. Abingdon: Routledge.

Danermark, B., Ekström, Jakobsen, L., \& Karlsson, J. C. (2002). Explaining society. Critical realism in the social sciences. Abingdon: Routledge.

Denzin, N. K., \& Lincoln, Y. S. (1994). Handbook of qualitative research. Newbury Park: Sage.

Doty, R. L. (2003). Anti-immigrantism in western democracies. Statecraft, desire and the politics of exclusion. London/New York: Routledge.

Elder-Vass, D. (2010). The causal power of social structures: Emergence, structure and agency. Cambridge: Cambridge University Press.

Elder-Vass, D. (2012). The reality of social construction. Cambridge: Cambridge University Press.

Fairclough, N. (2003). Analysing discourse. Textual analysis for social research. Abingdon: Routledge.

Fairclough, N. (2005). Discourse analysis in organizational studies: The case for critical realism. Organization Studies, 26(6), 915-939.

Fairclough, N., Jessop, B., \& Sayer, A. (2004). Critical realism and semiosis. In J. Joseph \& J. M. Roberts (Eds.), Realism discourse and deconstruction (pp. 23-42). Abington: Routledge.

Fleetwood, S. (2005). Ontology in organization and management studies: A critical realist perspective. Organization, 12(2), 197-222.

Geiger, M., \& Pécoud, A. (Eds.). (2012). The new politics of international mobility. Migration management and its discontents. Osnabrück: IMIS-BEITRÄGE (Institut für Migrationsforschung und Interkulturelle Studien (IMIS) Universität Osnabrück).

Genova, D. N. (2002). Migrant 'illegality' and deportability in everyday life. Annual Review of Anthropology, 31, 419-447.

Georgi, F., \& Schatral, S. (2012). Towards a critical theory of migration control: The case of the International Organization for Migration (IOM). In M. Geiger, \& A. Pécoud (Eds.), The new politics of international mobility. Migration management and its discontents (pp. 193-223). Osnabrück: IMIS-BEITRÄGE (Institut für Migrationsforschung und Interkulturelle Studien (IMIS) Universität Osnabrück).

Glick Schiller, N. (2007). Beyond the nation state and its units of analysis: Towards a new research agenda for migration studies. In K. Schittenhelm (Ed.), Concepts and methods in migration research, Conference Reader, 39-72. http://www.cultural-capital.net. Accessed 20 Sept 2010.

Hammersley, M. (2008). Questioning qualitative inquiry. Critical essays. London: Sage.

Hammersley, M. (2009). Challenging relativism. The problem of assessment criteria. Qualitative Inquiry, 15(1), 3-29.

Harding, S. (1993). Rethinking standpoint epistemology: What is 'strong objectivity'? In L. Alcoff \& E. Potter (Eds.), Feminist epistemologies (pp. 49-82). London: Routledge.

Hartwig, M. (Ed.). (2007). Dictionary of critical realism. Abingdon: Routledge.

Hayter, T. (2004). Open borders. The case against immigration control (2nd ed.). London: Pluto Press.

Hibberd, F. J. (2005). Unfolding social constructionism. New York: Springer.

Iosifides, T. (2008). Qualitative research methods in social sciences. Athens: Kritiki (in Greek).

Iosifides, T. (2011a). Qualitative methods in migration studies. A critical realist perspective. Farnham: Ashgate Publishing.

Iosifides, T. (2011b). A generic conceptual model for conducting realist qualitative research: Examples from migration studies (Working Paper No 43). International Migration Institute (IMI), University of Oxford, UK. http://www.imi.ox.ac.uk/pdfs/imi-working-papers/wp11-43-a-generic-conceptual-model-for-conducting-realist-qualitative-research-examplesfrom-migration-studies.10. Accessed May 2017.

Iosifides, T. (2012). Migration research between positivistic scientism and relativism: A critical realist way out. In C. Vargas-Silva (Ed.), Handbook of research methods in migration (pp. 26-49). Cheltenham: Edward Elgar. 
Iosifides, T., \& Sporton, D. (2009). Editorial: Biographical methods in migration research. In Iosifides \& Sporton (Eds.), Migration Letters, An International Journal of Migration Studies, Special Issue: Biographical Methods in Migration Research, 6(2), 101-108.

Karyotis, G., \& Skleparis, D. (2014). Migrant lived experiences and resistance to securitisation of migration in Greece: The modern 300 (GPSG Working Paper No 18). London: Greek Politics Special Group, Political Studies Association.

Laclau, E., \& Mouffe, C. (1985). Hegemony and socialist strategy. Towards a radical democratic politics. London: Verso.

Leontidou, L. (2005). Ageographitos Chora. Greek Hellenic idols in the epistemological reflections of European geography. Athens: Propompos (in Greek).

Lim, S.-L., \& Wieling, E. (2004). Immigrant Chinese American women: Negotiating values and perceptions of self in the cultural borderlands of east and west: A qualitative study. The Family Journal: Counselling and Therapy for Couples and Families, 12(2), 148-158.

Manicas, P. T. (2009). Realist metatheory and qualitative methods. Sociological Analysis, 3(1), $1-15$.

Moya, P. M. L. (2000). Postmodernism, "realism", and the politics of identity. Cherríe Moraga and Chicana feminism. In P. M. L. Moya \& M. R. Hames-García (Eds.), Reclaiming identity. realist theory and predicament of postmodernism (pp. 67-101). Los Angeles: University of California Press.

Moya, P. M. L. (2011). Who we are and from where we speak. Transmodernity. Journal of Peripheral Cultural Production of the Luso-Hispanic World, 1(2), 79-94.

Nellhaus, T. (2001). Signs, social ontology, and critical realism. Journal of the Theory of Social Behaviour, 28(1), 1-24.

Outhwaite, W. (1998). Realism and social science. In M. Archer, R. Bhaskar, A. Collier, T. Lawson, \& A. Norrie (Eds.), Critical realism, Essential Readings (pp. 282-296). London: Routledge.

Potter, G. (2001). Truth in fiction, science and criticism. In J. López \& G. Potter (Eds.), After postmodernism. An introduction to critical realism (pp. 183-195). London: Continuum.

Potter, G., \& López, J. (2001). After postmodernism: The new millennium. In J. López \& G. Potter (Eds.), After postmodernism. An introduction to critical realism (pp. 3-16). London: Continuum.

Sayer, A. (1992). Method in social science. A realist approach (2nd ed.). London: Routledge.

Sayer, A. (2000). Realism and social science. London: Sage Publications.

Scripta, A. (2013). Almost invisible. The illegalization of labour as state strategy for migration. Athens: Antifa Scripta.

Skleparis, D. (2016a). (In)securitization and illiberal practices on the fringe of the EU. European Security, 25(1), 92-111.

Skleparis, D. (2016b). The politics of migrant resistance amid the Greek economic crisis. International Political Sociology, 0, 1-17. doi: https://doi.org/10.1093/ips/olw014.

Squire, V. (2009). The exclusionary politics of asylum. Houndmills: Palgrave Macmillan.

Tsiolis, G. (2006). Life histories and biographical narratives. The biographical approach in sociological qualitative research. Athens: Kritiki (in Greek).

Tsiolis, G. (2014). Methods and analysis technics in qualitative social research. Athens: Kritiki (in Greek).

Walby, S. (2007). Complexity theory, systems theory, and multiple intersecting social inequalities. Philosophy of the Social Sciences, 37(4), 449-470.

Walby, S. (2009). Globalization and inequalities. Complexity and contested modernities. London: Sage.

Weiss, A., \& Nohl, A.-M. (2012). Overcoming methodological nationalism in migration research: Cases and contexts in multi-level comparisons. In A. Amelina, D. D. Nergiz, T. Faist, \& N. Glick Shiller (Eds.), Beyond methodological nationalism. Research methodologies for cross-border studies (pp. 65-90). New York: Routledge.

Wengraf, T. (2001). Qualitative research interviewing. London: Sage. 
Willis, J. W. (2007). Foundations of qualitative research. Interpretive and critical approaches. London: Sage.

Wimmer, A. (2007). How (not) to think about ethnicity in immigrant societies. Toward a boundarymaking perspective. In K. Schittenhelm (Ed.), Concepts and methods in migration research (pp. 7-38). http://www.cultural-capital.net. Accessed 20 Sept 2010.

Wimmer, A. (2008). The making and unmaking of ethnic boundaries: A multilevel process theory. American Journal of Sociology, 113(4), 970-1022.

Open Access This chapter is licensed under the terms of the Creative Commons Attribution 4.0 International License (http://creativecommons.org/licenses/by/4.0/), which permits use, sharing, adaptation, distribution and reproduction in any medium or format, as long as you give appropriate credit to the original author(s) and the source, provide a link to the Creative Commons license and indicate if changes were made.

The images or other third party material in this chapter are included in the chapter's Creative Commons license, unless indicated otherwise in a credit line to the material. If material is not included in the chapter's Creative Commons license and your intended use is not permitted by statutory regulation or exceeds the permitted use, you will need to obtain permission directly from the copyright holder. 